such a self-styled body. We have no observations to make upon the objects and activities of the two bodies of this type referred to above, but scientific workers must themselves decide whether either a "Faculty" or "College", constituted as we have stated, merits their support.

\section{Major E. E. Austen}

Major E. E. Austen retired from the keepership of the Department of Entomology in the British Museum (Natural History) on October 19, when he reached the age limit of sixty-five years. After an education at Rugby School and the University of Heidelberg, he entered the service of the Trustees of the British Muscum as second class assistant (now termed assistant keeper) in what was then the entomological section of the Department of Zoology on October 30,1899, and was placed in charge of the Diptera; to this group of insects he has dovoted his scientific life. The entomological section was soparated from the Department of Zoology in 1913 with Dr. C.J. Gahan as the first keeper; on his rotirement, Major Austen succeeded to the office on January 21, 1927. His last official act was to bring out the long wanted number on Clothes Moths and House Moths in the Natural History Museum economic series. As the blood-sucking flies are in the group studied by him, he has been brought closely into contact with tropical medicine. Ho was with the first expedition of the Liverpool School of Tropical Medicine to Sierra Leono in 1899, and has been a member of the council as well as vice-president of the Royal Society of Tropical Medicine and Hygiene. He has served on many committees including those on sleeping sickness, tsetse fly, and locust. $\mathrm{He}$ is a member of the committeo of management of the Imperial Institute of Entomology. In early days a volunteer and later a territorial, he saw service in the Boor War and in the European War; in the latter he was twice mentioned in dispatches and was awarded the Distinguished Service Order. Mr. N. D. Riley succeeds Major Austen as keeper, and Mr. K. G. Blair has been appointed deputy keeper in the Department of Entomology of the Museum.

\section{The Asiatic Society of Bengal}

Although scientific workers in many fields are familiar with the publications of the Asiatic Society of Bengal, few, probably, are aware of the mass influence of this ancient foundation upon Indian progress. A glimpse of the long history of the Society was given by Dr. Rai Upendra Nath Brahmachari, in his presidential address in 1929 , just published in the Journal and Proceedings (N.S., vol. 25, 1932). Founded in 1784, as the result of an appeal by Sir William Jones for the institution of a society to inquire into the history, civil and natural, the antiquities, arts, sciences and literature of Asia, and numbering amongst its early patrons Warren Hastings and Lord Cornwallis, the Asiatic Society set going inquirics of a kind which had fallen into abeyance in the India of the late eighteenth century. Its "Asiatic Researches" created so great an impression in the literary world that in 1798 a pirated edition was brought out in England, and on the Continent a French edition, "Recherches Asiatiquos", appeared in Paris. So early as 1808, a year after the formation of the Geological Society of London and only eighteen years after Werner had propounded at Freiburg his doctrine of "Formations", a special committee was formed "to propose such plans and carry on such correspondence as might seem best suited to promote the Natural History, Philosophy, Medicine, improvements of the Arts and Sciences and whatever is comprehended in the general term Physics".

AT first geology and mineralogy recoived most attention, and the names of many distinguished workers figure amongst the early contributorsVoysey the father of Indian geology, Oldham who created the Geological Survey of India, Lambton of the Indian Survoy, Schwendler one of the chief founders of the Calcutta Zoological Gardens, Falconer, Cautley, Colvin, Baker, Durand, to mention a few. Indeed there are few activities in the scientific life of India which have not been linked with the Asiatio Society, from the early othnological survey of Col. Dalton, and the grand series of papers on the fossil mammalian fauna of the Sub-Himalayas, to the foundation of the Indian Museum and its off-shoot the Zoological Survey. The president added a note of warning about the risk of starting now scientific periodicals, the competition of which might result in the double misfortune of loss both to the new and the old, and made a plea for consideration of the possibility of concentrating upon the oldest journal of all, the Journal of the Asiatic Society of Bengal, with which, he considers, many of the new journals might be amalgamated profitably.

\section{Ultra-Short Wave Radio Link across Bristol Channel}

ONE of the results of the study of the mode of propagation of ultra-short electric waves has been to show that for wave-lengths of from one to about nine metres, the effective range is limited to the horizon or the optical distance for ordinary vision. While this property prevents the application of such waves for long distance radio communication, it has for some timo been rocognised that this range of wave-lengths would be very suitable for providing a radio link in the ordinary telephone system. This application is of particular advantage in spanning short stretches of water, such as a channel or river estuary, where the prosont alternative is a submarine cable or a land-line following a circuitous route. According to recent reports in the Times and the Wireless World, the Post Office Engineering Dopartment has been investigating tho possibilities of this application for some time past, and exporiments have now successfully terminated in the setting-up of a radio link across the Bristol Channel. This link, which is twelve miles long, connects up the ordinary tolophone land-lines at Lavernock, near Cardiff, on one side, with those at Hutton, near Weston-superMare, on the other. The wave-length employed is about five metres, and the transmitters and receivers are placod in separate huts at each site. The aerial

No. 3286, Vol. 130] 
system consists of horizontal dipoles connected to the terminal apparatus by special transmission lines, and the whole equipment has been designed to work unattended, apart from periodic maintenance operations.

\section{British Standard Specifications}

The British Standards Institution has for its principal object the co-ordination of the efforts of producers and users for the improvement, standardisation, and simplification of engineering and industrial materials. It specifies standards both of quality and of dimensions in order to assist production and distribution and to eliminate waste of time and material involved in the unnecessary variation of articles made for the same purpose. Thereby it contributes to safety as well as to efficiency in industry, as is evidenced by the recent publication of a British standard specification for the identification of chemical pipe lines. The proposed scheme, which was prepared at the joint request of the British Chemical Manufacturers' Association and the British Chemical Plant Manufacturers' Association, identifies the nature of the liquids or gases conveyed by means of coloured plates, bearing a distinctive letter or sign, which are to be placed adjacent to the control valve and at intervals along the pipe. Thus a workman can immediately ascertain whether a certain pipe conveys inflammable, explosive, toxic, or corrosive material, whether the contents aro under pressure, or whether the pipe line is safe. The matter might at first sight appear to be a trivial one which could be left to the common sense of works managers; in practice, however, the proposed universal device will help to avoid the possibility of emergencies ending in tragedies.

\section{Research on Coal and Coke}

THE third annual report of the Northern Coke Research Committee records the many-sided activities of its staff working in the Armstrong College, Newcastle, on problems of the coals and cokes of the north of Fingland. Like most organisations, the Committee now labours under restrictions imposod by the financial stringencies of the times. Apart from fundamental long-range investigations, there is an immediate need for documented information about the characteristics of commercial fuels, which is felt by anyone concerned with the rational choice and utilisation of available coals. To-day coal is no longer the unchallenged king of fuols. The tendency with all commodities is to look for products regular in supply, of high and uniform quality. In all these respects coal has displayed an inferiority against its competitors, and it is hard to see how the industry can maintain its position against its cornpetitors by abandoning or diminishing efforts to inform itself about the properties of its wares. The Report for 1930-31 of the Department of Mining and Fuel Technology of the University of Shefficld also records a wide range of investigations connected with the winning and utilisation of coal, many of which have already been noticed in our pages.

\section{Modern Tendencies in Bird Taxonomy}

The appearance of a fourth edition of the American Check List of Birds in 1931 has suggested to Joseph Grinnell a comparison between its contents and that of previous editions (Auk, Jan. 1932, p. 9). The result is a vivid picturo of the tendency of modern taxonomic studies. The first edition appeared in 1886 , and subsequent editions in 1895,1910 , and now the fourth in 1931. The total number of forms, species, and sub-species listed in these editions was 951, 1068, 1196 , and 1420, a very considerable increase in about a working life-time. But a further examination shows that the increase is not equally distributed: the numbers of full species were 768,799, 802 and 811 , a remarkable stability of numbers during the period, less than one new species a year being described. On the other hand, the number of sub-spocies has mounted very greatly-183, 269, 394 and 609 -and the tendency to multiply sub-species is shown most strongly in the last edition. There has been a great advance in the identification of fossil species, the numbers of which run, $46,64,72$, and 156 , but this is a very natural development, for recent years have seen intensive fossil collecting in many areas. The author's idea is that the tendency marked in the new edition is bound to grow, that interest in phylogeny and species-making are counterparts, and that the "species factory in nature is the only resort in final analysis for learning the true nature of the speciation process. More and more alert, students in the field of systematics will develop a facility and technique of discrimination scarcely to bo dreamed of now." On the other hand, it is possible that the future will bring, rather than a development of description for its own sake, an association between specific or subspecific forms and their environment so close that systematic description apart from referenco to pecu. liarities of life-conditions will be regarded as inadequate.

\section{Progress at Colombo Museum}

THE building of a new west wing, a new isolated archæological gallery for stone remains, and a small building for the entomologists' department and reserve collections, has provided nearly 13,000 square feet of additional space for the public collections of the Colombo Muscum. The exterior of the west wing conforms with the style of the older portion of the museum, and the block, which, as a photograph shows, is a very handsome structure, stands out as one of the finest buildings in Colombo. It is illustrative of the difficulties of museum lighting that although at most seasons the light is too intense for spocimens and sight-seeing, during cloudy days in the monsoon period the lighting in the old building was found to be inadequate, and accordingly special provision has been made for artificial lighting from the roof and within the cases (Administration Report of the Director of the Colombo Museum for 1931). Many additions have been made to the Museum collections, but the section which still retains greatest hold upon the visitor is the collection of living animals, which contains a good selection of mammals 